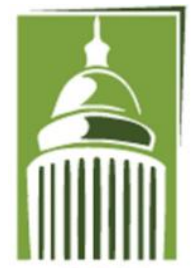

A R F
Global Proceedings Repository

American Research Foundation

ISSN 2476-017X

Available online at http://proceedings.sriweb.org

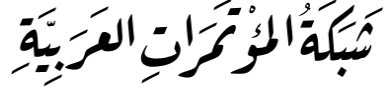

http://arab.kmshare.net/

First Forum on Gifted Education in Lebanon

$$
27 \text { تشرين الأول } 2017 \text { فندق ديونز - فردان، بيروت، الجمهورية اللبنانية }
$$

\title{
Parents' and Educators' Unawareness of the Needs of the Gifted Students and Its Effect on Their Learning and Productivity in Schools of Beirut
}

\section{Riam Shaer}

\begin{abstract}
This study was conducted between March 2015 and February 2016 to describe the level of parents' and educators' awareness and check how it impacts the focus on gifted students. Both qualitative and quantitative methods were utilized in this study. For the qualitative approach, two in-depth interviews were conducted: the first with the director of education in Beirut, and the second with a psychologist and a special education coordinator at a reputable school in Beirut. In addition, 60 parents and 60 teachers completed different questionnaires to meet the quantitative demands of the study. Data was collected and analyzed from both instruments; questionnaires and interviews
\end{abstract}




\section{Global Proceedings Repository \\ American Research Foundation}

ISSN 2476-017X

Available online at http://proceedings.sriweb.org

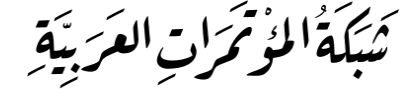

http://arab.kmshare.net/

A R F

revealed that attention to the gifted students deteriorate and almost vanish when parents and educators do not realize the careless attitude directed to this group, do not recognize the essential needs this group requires, and do not work on putting stepping stones towards enhancement.

Keywords: Neglect, Gifted, Awareness, Parents, Teachers, Learning

\section{Introduction}

All persons, in all regions, of all economic statuses should have access to free education. Students have different potentials, learning styles, needs, and talents. Educational programs should take into account all the above diversities (Mayor, 1994). To combat exclusion and reach equity in learning, the delegates of the World Conference on Special Needs Education in Salamanca, Spain, explain that equal opportunities should be provided for all categories of learners including disabled students and gifted ones.

Davis \& Rimm (1989) demonstrate the situation gifted students are passing through as such: 


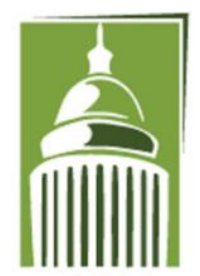

A R F

\section{Global Proceedings Repository \\ American Research Foundation}

ISSN 2476-017X

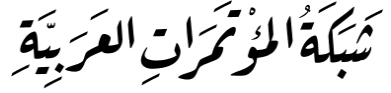

http://arab.kmshare.net/

Available online at http://proceedings.sriweb.org

Tens of thousands of gifted and talented children and adolescents are sitting in their classrooms- their abilities unrecognized, their needs unmet. Some are bored, patiently waiting for peers to learn skills and concepts that they had mastered one or two years earlier. Some find school intolerable feigning illness or creating other excuses to avoid that trivia. Many develop poor study habits from the slow pace and lack of challenge. Some feel pressured to hide their keen talent and skills from uninterested and unsympathetic peers. Some give up on school entirely, dropping out as soon as they are legally able. Some educators call it a quiet crises (p. 1).

Sarouphim (2010) states that Lebanon lacks programs for the gifted. Few private schools in Beirut provide enrichment programs for high achievers of high socioeconomic ranks. Even those are insufficient.

CERD (1995) gives an overview of the educational system in Lebanon. Lebanese public and private schools have adopted the unified national curriculum obligated by the Ministry of Education (MOE) which mandates considering students with special needs. However, provisions offer services only for students with learning difficulties. Moreover, the Lebanese Parliament has projected a spy glass on students with learning difficulties. In May 2000, it legislated schemes for these students and preserved their right for equal 


\section{Global Proceedings Repository \\ American Research Foundation}

ISSN 2476-017X

Available online at http://proceedings.sriweb.org

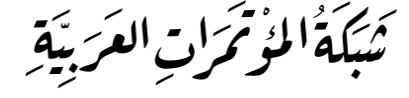

http://arab.kmshare.net/

AR F

education as any of their peers (Wehbi, 2006). However, these measures did not consider the needs of gifted students. The former minister of Education and Higher Education, Hassan Diab has acknowledged the deprivation suffered by gifted students; he has launched a national plan in 2012 to ensure including all students with special needs into the education system (The Daily Star, 2012). This plan includes the development of a national curriculum, the training of teachers to work with students of special needs and a testing compound to help gauge student progress. However, this plan was not implemented since lots of procedures and requirements are needed (Hamiyeh, 2012).

Based on the above evidence, gifted students in Lebanon are victims of this crisis. Even though efforts have emerged to help gifted students, these attempts are still not founded on solid grounds. Lebanese gifted students urgently call for a change.

Prominently, people in charge should exert more effort and tap into the country's potential resources.

\section{Statement of the Problem}

As any learner, gifted students should receive equal opportunities that unveil their hidden potentials and develop them. Unfortunately, gifted students in Beirut are deprived of chances to excel. They are overlooked basically because they are considered as capable of maintaining their needs without any additional support. 


\section{Global Proceedings Repository \\ American Research Foundation}

ISSN 2476-017X

Available online at http://proceedings.sriweb.org

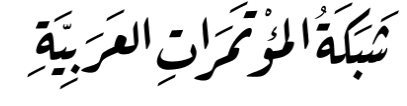

http://arab.kmshare.net/

A R F

\section{Research Questions}

H1 Are teachers aware of the gifted needs?

H2 Are parents aware of the gifted needs?

\section{Significance}

Gifted students are fortunes to the country and the source of tomorrow's change. Their learning and development should be of priority in any country. However, the lack of attention they are receiving in Beirut, triggered the researcher to dig deeper into the causes of such negligence. Considering parents and educators as the main channels that affect the growth of young minds, the study utilized questionnaires and interviews to investigate reasons behind their indifference toward gifted students. The instruments employed in this study were designed to help parents and educators realize the carelessness they are practicing toward the gifted as well as make them acknowledge the need for new strategies to help these students reach their full potential. Only when society members know who the gifted are, what their needs are, how they can be identified, why it is important to nurture their potentials, and what programs are best to help upgrade their needs, will gifted negligence come to an end. Assuming a change in behavior toward gifted learning without raising society awareness is a total absurdity. Potentials of 


\section{Global Proceedings Repository \\ American Research Foundation}

ISSN 2476-017X

Available online at http://proceedings.sriweb.org

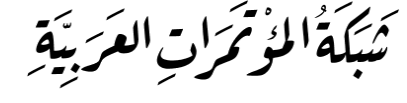

http://arab.kmshare.net/

A R F

gifted students will be considered and worked on, once those in charge acquire an understanding of the necessity to change.

\section{Literature Review}

\section{Definition of Giftedness}

Davis \& Rimm (1989) explain how the definition of giftedness evolved through the years and upon different cultures. Giftedness according to the Spartans was associated with physical strength, whereas Athenians linked giftedness to gender and social positions. Boys of the upper class were considered capable no matter what. In Japan, and between the years 1604 and 1868, giftedness was once more related to Samurai children and not to commoners.

Each culture view giftedness according to its values and interests (Gallager \& Gallager, 1994). In America, and between the 1920s and 1930s, the interest in detecting giftedness faded. There was a major focus on equity and people were mainly concernedwith survival during that period of great depression. However, this concern reignited later in the mid-1970s where the majority of the states adopted the definition of giftedness from the original definitions made by Maryland (1972) and later on by Javits (1988). 


\section{Global Proceedings Repository \\ American Research Foundation}

ISSN 2476-017X

Available online at http://proceedings.sriweb.org

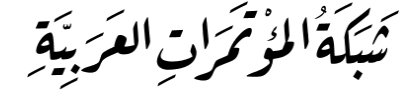

http://arab.kmshare.net/

AR F

Maryland's definition 1972, as cited by Gallager \& Gallager (1994), is as

follows:

Gifted and talented children are those identified by professionally qualified persons who by virtue of outstanding abilities are capable of high performance.

These are children who require differentiated educational programs and services beyond those normally provided by the regular school program in order to realize their contribution to self and society. Children capable of high performance include those with demonstrated achievement and/or potential ability in any of the following areas:

1- General intellectual aptitude

2- $\quad$ Specific academic aptitude

3- Creative or productive thinking

4- $\quad$ Leadership ability

5- Visual and performing arts

6- Motor abilities (p. 5)

Javit's definition 1988, as cited by Gallager \& Gallager (1994), is as follows:

Gifted and talented student mean children and youths who: 


\section{Global Proceedings Repository \\ American Research Foundation}

ISSN 2476-017X

Available online at http://proceedings.sriweb.org

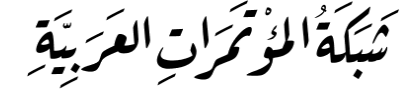

http://arab.kmshare.net/

A R F

1- Give evidence of higher performance capabilities in such area as intellectual, creative, artistic, or leadership capacity or in specific academic field ; and who

2- Require services or activities not ordinarily provided by the schools in order to develop such capabilities fully (p. 5).

In the 1990s, many laws where set by the U.S. government and all the states regarding gifted education; many states as well allocated funds for this cause (Goodhew, 2009). Gallager \& Gallager (1994) say that there are two broad perspectives about the components of giftedness. One perspective considers a gifted child as one who has potentials for excellence on the long run. This perspective does not limit giftedness to the child's current productivity, whereas the second perspective considers the actual production of exceptional work as the basic component of giftedness.

Renzulli (1998) views giftedness as the interaction among the three components: above average ability, task commitment, and creativity. His three - ringed concept of giftedness explains that a child of above average ability and not only that of an exceptional one is able to show giftedness if he is task committed and creative. He continues to say that the first component which is ability is fixed; however the other two components creativity and task commitment are not. They are subject to change 


\section{Global Proceedings Repository \\ American Research Foundation}

ISSN 2476-017X

Available online at http://proceedings.sriweb.org

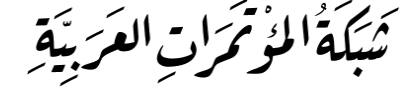

http://arab.kmshare.net/

AR F

depending on the stimuli. Stimuli range from educational tools and provisions up to the human factor that is instructors. Renzulli's approach does not restrict giftedness only to those with high IQ scores; it rather opens up the opportunity to a wide range of above average ability students to be part of the potential giftedness.

Columbus Group (2012) claims in their definition of giftedness that for the maximum progress of gifted students, parents, teachers, and counselors should admit the fragility of these students. Then they should alter their approaches while dealing with them. Siegle \& McCoach (2005) demonstrate that gifted capabilities come to light after the welcoming perceptions they receive from their surroundings: teachers, peers, and parents. These sayings get us closer to answer the following question: who has a role to play in the gifted development?

\section{Role of Teachers}

Renzulli's (1998)perspective of giftedness highlighted the role of teachers in the nurturing of these students. It is the job of exciting instructors to rekindle students to become more involved. Goodhew (2009) explains that a teacher's class observation, although not the only mean, is a key to identify giftedness. However, the teacher's job does not stop at this end. It is only a starting point for a series of steps to be followed to secure the embracing of all aspects related to the progress of gifted students. He recalls 


\section{Global Proceedings Repository \\ American Research Foundation}

ISSN 2476-017X

Available online at http://proceedings.sriweb.org

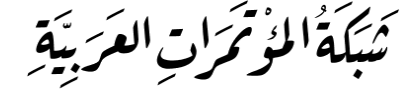

http://arab.kmshare.net/

A R F

sayings mentioned by adults of how the cause behind their success refers to a teacher who admitted their excellence and motivated them to make use of it. Those teachers believed that these students will achieve and their belief was the basic motive behind their students' advancement.

Everstone \& Emmer (2003) affirm that the way a teacher reacts to gifted students reveals to them that he or she values their capacities and interests. Johnson (2011) recalls the claim of the two psychologists Abraham Maslow and Howard Gardener that every student is gifted at something. Johnson then adds that it is the duty of the teacher to assist to the shinning of these talents through modifying their instructional repertoire.

\section{How Can Teachers Help?}

At many times, gifted students may consider tasks trivial, and might therefore deviate their attention away from the ongoing performance tasks within class. For this, Siegle \& McCoach (2005) advise teachers to explain to students the purpose to be covered in a given task. This will assist students in knowing the benefit of applying the required objectives. To them, teachers can seek the participation of various community members such as parents. Parents can display their experiences in front of these students and demonstrate to them how the skills they acquired in school were used later in their daily life. These multiple participations would steer bored students to accept venturing 


\section{Global Proceedings Repository \\ American Research Foundation}

ISSN 2476-017X

Available online at http://proceedings.sriweb.org

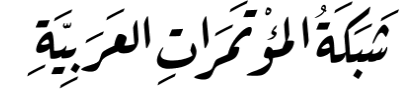

http://arab.kmshare.net/

A R F

through uninteresting topics in school. They would realize the fruitful rewards of school work such as getting accepted in reputable universities, getting scholarships, or attaining excellent job offers. They add that instructors should put the gifted students' interests into their teaching. They should take into account their students' interests and provide them with freedom to select the tasks they prefer. They should offer challenging situations for these students before boredom captivates them.

Johnson (2011) highlights three actions required by the teachers of the gifted: identification, acceptance, and utilization. Identification is the stage by which teachers are supposed to notice and recognize the area of excellence of a child. Davis \& Rimm (1989) introduce a number of strategies for identification such as intelligence scores, recognizing multiple forms of intelligence, and considering cultural differences; as well as considering teachers', parents', peers', and individuals' nominations, achievement tests, and product evaluations. To them, identification is a critical step; it should not be biased. It has to take into account the multi strategies of the above mentioned. Then, the teacher's second action should be that of acceptance of a special capacity or talent the child has. Johnson (2011) explains that this step is even tougher than the first one. The teacher should balance maintaining equity among students and encouraging exceptional talents in class. Lastly comes the stage of utilization. It is through this stage that teachers put 


\section{Global Proceedings Repository \\ American Research Foundation}

ISSN 2476-017X

Available online at http://proceedings.sriweb.org

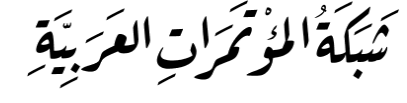

http://arab.kmshare.net/

A R F

practical plans and programs that aim toward the gifted enhancement. Two well-known approaches of programming for gifted learning are acceleration and enrichment. These two approaches are accommodations for students with high abilities. They define acceleration as moving faster through academic content which typically includes offering standard curriculum to students at a younger than usual age; whereas enrichment refers to richer and more varied educational experiences, that is to provide greater depth and breadth than is generally provided.

Moreover, Davis \& Rimm (1989) present 12 procedures for acceleration: early entrance, non-graded classes, grade telescoping, subject acceleration, mentorships, credit by examination, combination of two options, grade skipping, curriculum compacting, concurrent enrollment (high school and college), advanced placement courses, and early admission to college. All of which proved no decrease in performance field of the gifted but resulted in a positive effect. Furthermore, they display 11 forms of enrichment: independent study and independent projects, learning centers, field trips, Saturday programs, summer programs, mentors and mentorships, future problem solving, odyssey of the mind, junior great books, academic competitions, and using technology. These forms are a plus and an advantage to all students and are not restricted only to the gifted. Both acceleration and enrichment accommodate the high abilities and needs of gifted 


\section{Global Proceedings Repository \\ American Research Foundation}

ISSN 2476-017X

Available online at http://proceedings.sriweb.org

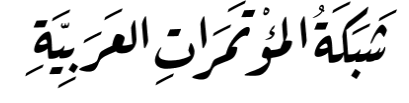

http://arab.kmshare.net/

AR F

students. Both lead to greater knowledge and skills and both help develop creativity and other thinking skills.

\section{Role of Parents}

Winebrenner (2001) proclaims that teachers are not the only ones in charge of raising the gifted students; parents also play a major role in their development. These two should cooperate to provide suitable chances that assure the growth of the gifted at home as well as in school. Parents should not by any means suppose that the school has the exclusive role to play with their gifted children, they should instead be aware that their children cannot reach maximum results without their coordination with school teachers.

Balley (2014) declares that parents should work hand in hand with the school instructors and counselors to convey to them their gifted children's difficulties. Goodhew (2009) celebrates the victory on old days where parents were deprived of their rights to express their opinions, suggestions, notes, or any recommendations concerning their children. He, as well, highlights the noticeable part played by parents and the community and explains their effect on the progress of the gifted.

Hall \& Skinner (1980) explain that parents are the ones to assist their gifted children to reach more and more productivity. Witty (1980) claims that the primary 


\section{Global Proceedings Repository \\ American Research Foundation}

ISSN 2476-017X

Available online at http://proceedings.sriweb.org

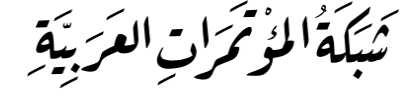

http://arab.kmshare.net/

A R F

teachers of gifted children are their parents. They have wider chances to teach their children by modeling and through setting suitable standards for their children to follow.

\section{How Can Parents Help?}

Goodhew (2009) states that parents can supply the school teachers with a beneficial information about their children. Parents ought to tell teachers about their children's tendencies. They have to assist school teachers in designing convenient IEPs that would fit their children. They can as well inform the school about the availability of outside institutions that can aid the school in its planning.

Witty (1980) adds that parents should always answer, guide, and give examples to their children. They should provide appropriate resources such as books, magazines, puppets, musical instruments, crayons, and art shows. It is of great importance to encourage children, open up chances for them to express, and be creative (Balley, 2014). Parents should not shut their children's eagerness to learn more and they should not be acting as delay mechanisms for their children's exceptional lust. Parents can give their children the opportunity to play with household stuff which will boost their creativity. Parents should scaffold the difficulty of the games their children play. They can do a number of steps as in helping their children with research and trying to connect with support groups or through the social media. 


\section{Global Proceedings Repository \\ American Research Foundation}

ISSN 2476-017X

Available online at http://proceedings.sriweb.org

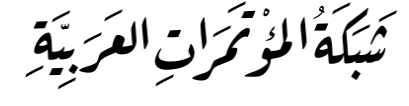

http://arab.kmshare.net/

A R F

\section{Methodology}

Qualitative and quantitative strategies are employed in this study to show the existence of illiteracy when it comes to gifted learning. In depth interviews were conducted and questionnaires were utilized to prove the need for raising awareness about gifted students.

\section{Population and Sample}

Data are drawn from the two interviews: the first with the director of education in Beirut, Lebanon and the second with a special education coordinator and a psychologist at a private school in Beirut- Lebanon.

Moreover, data was drawn from a random sample of 60 teachers and 60 parents in Beirut - Lebanon between December 2015 and January 2016. This population was chosen because of the many studies that put emphasis on the fact that parents and teachers are the rock bottom of the students' learning and development since they engage in daily interaction with their needs, changes, and growth. No payment was made to the participants and they were assured of anonymity and confidentiality of information provided.

\section{Instruments}

Two different instruments were used in this study. On one hand, interviews were conducted to support the qualitative course of the study. The first interview comprised of 


\section{Global Proceedings Repository \\ American Research Foundation}

ISSN 2476-017X

Available online at http://proceedings.sriweb.org

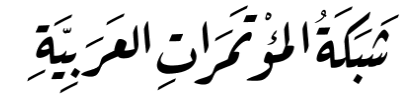

http://arab.kmshare.net/

A R F

five open-ended questions, while the second interview had fifteen open-ended questions. Interviews were carried on different dates and each took no more than 60 minutes.

On the other hand, two different questionnaires were employed for the quantitative strategy. The first was directed to teachers and consisted of two parts. The first part encompassed closed ended profile questions covering the following topics: (1) graduation date, (2) university name, (3) faculty, (4) domain, (5) number of schools employed, (6) years of experience, and (7) teaching cycle. The second part of the questionnaire contained 11 items using a 5 point Likert scale with numerical values given to each one of the following responses as such:

1. never

2. seldom

3. sometimes

4. often

5. always

The second questionnaire was addressed to parents and it comprised of two parts. The first included closed ended profile questions as (1) number of children, (2) educational level, (3) current occupation, and (4) number of schools your children attended. The second part contained fourteen items divided into five areas using a five point Likert scale with numerical values given to each response as such: 


\section{Global Proceedings Repository \\ American Research Foundation}

ISSN 2476-017X

Available online at http://proceedings.sriweb.org

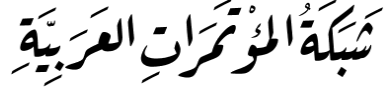

http://arab.kmshare.net/

A R F

1. never

2. seldom

3. sometimes

4. often

5. always

\section{Data Collection}

Teachers and parents questionnaires were distributed to four private schools in Beirut.

The principals of each of the schools were handled fifteen copies of each questionnaire to be filled on Monday, December $14^{\text {th }}, 2015$. School principals in turn passed them to supervisors who distributed them randomly on school teachers and walk in parents. The four schools submitted their copies to the researcher on the $21^{\text {st }}$ of December. These copies were then given to a specialist in statistics on the $22^{\text {nd }}$ of December to help in the data analysis process.

Table 1: present the number (percentage) of the corresponding possible answers for each question and the calculated mean rank obtained from the parents' questionnaire. Mean rank is between $0=$ never and $100=$ always.

\begin{tabular}{|l|l|c|c|c|c|c|c|}
\hline & Statements & $\begin{array}{c}\text { Never } \\
(=0)\end{array}$ & $\begin{array}{c}\text { Seldom } \\
(=25)\end{array}$ & $\begin{array}{c}\text { Sometimes } \\
(=50)\end{array}$ & $\begin{array}{c}\text { Often } \\
(=75)\end{array}$ & $\begin{array}{c}\text { Always } \\
(=100)\end{array}$ & $\begin{array}{r}\text { Mean rank } \\
(\text { out } 0 \text { f 100) }\end{array}$ \\
\hline 1. & Children have the same mental abilities. & 33 & 6 & 12 & 9 & 0 & 23.8 \\
\hline 2. & $\begin{array}{l}\text { Parents spend equal time teaching all } \\
\text { their children at home. }\end{array}$ & 12 & 15 & 17 & 14 & 2 & 41.3 \\
\hline
\end{tabular}


Available online at http://proceedings.sriweb.org

\begin{tabular}{|l|l|c|c|c|c|c|c|}
\hline 3. & $\begin{array}{l}\text { One of your children is facing academic } \\
\text { troubles at school. }\end{array}$ & 15 & 16 & 17 & 4 & 8 & 39.2 \\
\hline 4. & One of your children is exceptional. & 14 & 14 & 13 & 17 & 1 & 40.3 \\
\hline 5. & $\begin{array}{l}\text { You know the criteria that make a child } \\
\text { exceptional. }\end{array}$ & 15 & 9 & 18 & 13 & 5 & 43.3 \\
\hline 6. & $\begin{array}{l}\text { School instructors report child's } \\
\text { exceptional abilities to parents. }\end{array}$ & 13 & 20 & 8 & 8 & 11 & 43.3 \\
\hline 7. & $\begin{array}{l}\text { The school provides special services for } \\
\text { students with learning difficulties. }\end{array}$ & 10 & 10 & 10 & 11 & 19 & 57.9 \\
\hline 8. & $\begin{array}{l}\text { Students with learning difficulties require } \\
\text { more attention than their peers. }\end{array}$ & 4 & 1 & 9 & 11 & 35 & 80.0 \\
\hline 9. & $\begin{array}{l}\text { More attention should be on students } \\
\text { with exceptional abilities. }\end{array}$ & 3 & 9 & 13 & 8 & 27 & 69.6 \\
\hline 10. & $\begin{array}{l}\text { Parents have more awareness about } \\
\text { gifted students than students with }\end{array}$ & 10 & 16 & 16 & 8 & 1 & 37.3 \\
\hline
\end{tabular}

According to the results in the above table, the below can be concluded:

1. Responses with the highest frequency in statement one was 'never' with a ratio of 33/60, while responses with the lowest frequency was that of 'always' with a ratio of $0 / 60$.

2. Responses with the highest frequency in statement two was 'sometimes' with a ratio of $17 / 60$, while responses with the lowest frequency was that of 'always' with a ratio of $2 / 60$. 


\section{Global Proceedings Repository \\ American Research Foundation}

ISSN 2476-017X

Available online at http://proceedings.sriweb.org

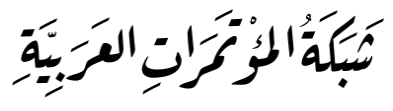

http://arab.kmshare.net/

A R F

3. Responses with the highest frequency in statement three was 'sometimes' with a ratio of $17 / 60$, while responses with the lowest frequency was that of 'often' with a ratio of 4/60.

4. Responses with the highest frequency in statement four was 'often' with a ratio of 4/60, while responses with the lowest frequency was that of 'always' with a ratio of 1/60.

5. Responses with the highest frequency in statement five was 'never' with a ratio of $33 / 60$, while responses with the lowest frequency was that of 'always' with a ratio of 0/60.

6. Responses with the highest frequency in statement six was 'seldom' with a ratio of 20/60, while responses with the lowest frequency was that of 'sometimes' and 'often' with a ratio of $8 / 60$.

7. Responses with the highest frequency in statement seven was 'seldom' with a ratio of $24 / 60$, while responses with the lowest frequency was that of 'always' with a ratio of $4 / 60$.

8. Responses with the highest frequency in statement eight was 'always' with a ratio of $35 / 60$, while responses with the lowest frequency was that of 'often' with a ratio of $1 / 60$. 


\section{Global Proceedings Repository \\ American Research Foundation}

ISSN 2476-017X

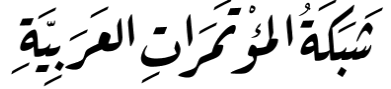

http://arab.kmshare.net/

ARF

Available online at http://proceedings.sriweb.org

9. Responses with the highest frequency in statement nine was 'always' with a ratio of $27 / 60$, while responses with the lowest frequency was that of 'never' with a ratio of $3 / 60$.

Responses with the highest frequency in statement ten was 'seldom' and 'sometimes' with a ratio of $16 / 60$, while responses with the lowest frequency was that of 'always' with a ratio of $1 / 60$.

Table 2: present the number (percentage) of the corresponding possible answers for each question and the calculated mean rank obtained from the teachers' questionnaire. Mean rank is between $0=$ never and $100=$ always .

\begin{tabular}{|c|l|c|c|c|c|c|c|}
\hline \multicolumn{2}{|c|}{ Statements } & $\begin{array}{c}\text { Never } \\
(=0)\end{array}$ & $\begin{array}{c}\text { Seldom } \\
(=25)\end{array}$ & $\begin{array}{c}\text { Sometimes } \\
(=50)\end{array}$ & $\begin{array}{c}\text { Often } \\
(=75)\end{array}$ & $\begin{array}{c}\text { Always } \\
(=100)\end{array}$ & $\begin{array}{c}\text { Mean } \\
\text { Rank } \\
(\text { out of } \\
100)\end{array}$ \\
\hline 1. & $\begin{array}{l}\text { You use the same technique with your } \\
\text { students in class. }\end{array}$ & 38 & 18 & 4 & 0 & 0 & 10.8 \\
\hline 2. & $\begin{array}{l}\text { You exert the same effort with your } \\
\text { students. }\end{array}$ & 26 & 13 & 21 & 0 & 0 & 22.9 \\
\hline 3. & $\begin{array}{l}\text { You encounter students with learning } \\
\text { difficulties. }\end{array}$ & 5 & 22 & 32 & 0 & 0 & 35.8 \\
\hline 4. & $\begin{array}{l}\text { The school management you are } \\
\text { employed in, offers special services for } \\
\text { students with learning difficulties. }\end{array}$ & 25 & 8 & 27 & 0 & 0 & 25.8 \\
\hline
\end{tabular}




\section{Global Proceedings Repository \\ American Research Foundation}

ISSN 2476-017X

Available online at http://proceedings.sriweb.org

\begin{tabular}{|c|l|c|c|c|c|c|c|}
\hline 5. & $\begin{array}{l}\text { You encounter students with } \\
\text { exceptional capabilities. }\end{array}$ & 18 & 19 & 23 & 0 & 0 & 27.1 \\
\hline 6. & $\begin{array}{l}\text { You report students with outstanding } \\
\text { performance to the heads of your } \\
\text { school. }\end{array}$ & 12 & 11 & 37 & 0 & 0 & 35.4 \\
\hline 7. & $\begin{array}{l}\text { The school management you are } \\
\text { employed in offers special services for } \\
\text { high ability students. }\end{array}$ & 34 & 16 & 9 & 0 & 0 & 14.2 \\
\hline 8. & $\begin{array}{l}\text { You received special training about the } \\
\text { needs of gifted students. }\end{array}$ & 46 & 4 & 10 & 0 & 0 & 10.0 \\
\hline 9. & $\begin{array}{l}\text { You received special training about the } \\
\text { needs of students with learning } \\
\text { difficulties. }\end{array}$ & 29 & 11 & 20 & 0 & 0 & 21.3 \\
\hline 10. & $\begin{array}{l}\text { Outstanding students receive better } \\
\text { education if present in a pull out } \\
\text { program. }\end{array}$ & 15 & 19 & 26 & 0 & 0 & 29.6 \\
\hline
\end{tabular}

According to the results in the above table we can conclude the following:

1. Responses with the highest frequency in statement one was 'never' with a ratio of $38 / 60$, while responses with the lowest frequency was that of 'always' and 'often' with a ratio of $0 / 60$.

2. Responses with the highest frequency in statement two was 'never' with a ratio of 26/60, while responses with the lowest frequency was that of 'always' and 'often' with a ratio of $0 / 60$. 


\section{Global Proceedings Repository \\ American Research Foundation}

ISSN 2476-017X

Available online at http://proceedings.sriweb.org

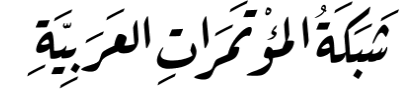

http://arab.kmshare.net/

A R F

3. Responses with the highest frequency in statement three was 'sometimes' with a ratio of $32 / 60$, while responses with the lowest frequency was that of 'always' and 'often' with a ratio of $0 / 60$.

4. Responses with the highest frequency in statement four was 'sometimes' with a ratio of 27/60, while responses with the lowest frequency was that of 'always' and 'often' with a ratio of $0 / 60$.

5. Responses with the highest frequency in statement five was 'sometimes' with a ratio of 23/60, while responses with the lowest frequency was that of 'always' and 'often' with a ratio of $0 / 60$.

6. Responses with the highest frequency in statement six was 'sometimes' with a ratio of $37 / 60$, while responses with the lowest frequency was that of 'always' and 'often' with a ratio of $0 / 60$.

7. Responses with the highest frequency in statement seven was 'never' with a ratio of 34/60, while responses with the lowest frequency was that of 'always' and 'often' with a ratio of $0 / 60$.

8. Responses with the highest frequency in statement eight was 'never' with a ratio of $46 / 60$, while responses with the lowest frequency was that of 'always' and 'often' with a ratio of $0 / 60$. 


\section{Global Proceedings Repository \\ American Research Foundation}

ISSN 2476-017X

Available online at http://proceedings.sriweb.org

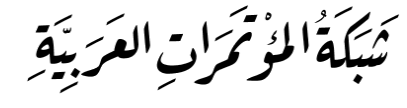

http://arab.kmshare.net/

A R F

9. Responses with the highest frequency in statement nine was 'never' with a ratio of 29/60, while responses with the lowest frequency was that of 'always' and 'often' with a ratio of $0 / 60$.

Responses with the highest frequency in statement ten was 'sometimes' with a ratio of $26 / 60$, while responses with the lowest frequency was that of 'always' and 'often' with a ratio of $0 / 60$.

\section{Summary}

This study attempted to shed the light on the level of societal awareness about gifted education. It also aimed to mark its effect on gifted students. Results of the study coincided with the hypotheses. Gifted students in Lebanon are marginalized due to community's - specifically parents and teachers - unawareness about their needs.

Qualitatively, interviews detected that parents, and teachers, are indifferent towards gifted students. HA students are not provided with any service. Funds are not allocated to supply requirements needed for their enhancement. Gifted students develop independently without any assistance from any source. Recommendations from interviews stressed that the stepping stone for a change in the indifference toward gifted students is enlightening the ones in charge with their needs. 


\section{Global Proceedings Repository \\ American Research Foundation}

ISSN 2476-017X

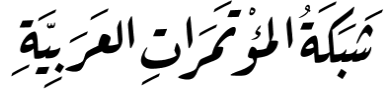

http://arab.kmshare.net/

Available online at http://proceedings.sriweb.org

Quantitatively, a number of issues were realized from the surveys conducted. At first, teachers' questionnaires showed that teachers are aware that students have different capacities and potentials. For that reason, they use various techniques to reach their students in classrooms (Fig. 22). Moreover, data from questionnaires revealed that high ability students are marginalized and the focus is projected more on LD students and schools provide more for LD students than services for HA ones (Fig. 25 and 28). At last, the data from the questionnaires indicated that teachers believe that gifted students receive better education when present in a pull-out program. This assumption is misleading and confusing for the majority of them who admitted to not receiving any workshops or trainings about gifted learners (Fig.29).

From the parents questionnaires, two conclusions were deduced. The first is the parents' affirmation that schools do not focus on students with high abilities since school managements do not provide enough services for gifted students (Fig. 11). The second obvious conclusion is that parents are conscious of children's different capabilities. $65 \%$ of them know that children have different abilities (Fig. 5). However, this knowledge is not sufficient to accommodate or cater for the needs of HA students, and this again is seen in (Fig. 9) where only $30 \%$ of the respondents confessed to knowing the criteria that make up an exceptional child. 


\section{Global Proceedings Repository \\ American Research Foundation}

ISSN 2476-017X

Available online at http://proceedings.sriweb.org

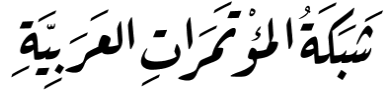

http://arab.kmshare.net/

A R F

In brief, the results of the questionnaires along with the declarations in the interviews reveal the following findings. Parents of different educational levels and working in different fields as well as teachers of various graduation dates, faculties, domains, years of experience, universities, and working in different cycles all lack awareness about gifted students. Gifted students need to receive more attention for their betterment, identification, and learning.

\section{Recommendations}

To promote gifted learners' capacities it is recommended that:

\section{Teachers:}

1. Take more workshops and awareness seminars about gifted students.

2. Recognize the identification techniques of these learners.

3. Recognize intervention strategies to promote these learners.

4. Implement identification and intervention programs that suit the upgrading of these high ability students.

\section{Parents:}

1. Attend awareness conferences to recognize the needs of these student.

2. Carryout steps to encourage and increase the capabilities of these learners. 


\section{Global Proceedings Repository \\ American Research Foundation}

ISSN 2476-017X

Available online at http://proceedings.sriweb.org

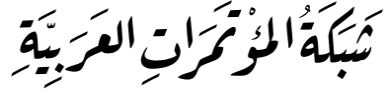

http://arab.kmshare.net/

A R F

3. Seek the assistance of support groups and institutes specialized in gifted education.

4. Inform school teachers about their child(ren) tendencies.

5. Assist in the IEP design.

\section{School Managers:}

1. Supply the tools, resources, workshops, training, and all required to enhance gifted learners' progress.

2. Provide gifted learners equal education opportunities as done to students with learning difficulties and encourage creativity among students.

\section{References}

Balley, N. (2014). Commiserating on how gifted students are ignored by educators, policymakers and those who should care. Retrieved from: http://nancyebailey.com/2014/09/12/commiserating-on-how-gifted-students-areignored-by-educators-policymakers-and-those-who-should-care/

Center for Educational Research and Development. (1995). Lebanon national curriculum. Beirut: Lebanon.

Columbus Group. (2012). Off the Charts, Asynchrony and the Gifted Child. Royal Fire Work press. Now York. U.S.A.

Davis, A.G., Rimm, B.S. (1989). Education of the gifted and talented. Pearson.

Everston, M.C. \& Emmer, E.T. (2003). Classroom management for elementary teachers. Pearson. MA: United States of America. 


\section{Global Proceedings Repository \\ American Research Foundation}

ISSN 2476-017X

Available online at http://proceedings.sriweb.org

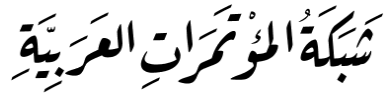

http://arab.kmshare.net/

ARF

Gallagher, J.J., Gallagher, A.S. (1994). Teaching the gifted child. Longman Higher Education. MA: United States of America.

Goodhew, G. (2009). Meeting the needs of gifted and talented. England: Bloomsbury Publishing.

Hall, G.E., Skinner, N. (1980). Somewhere to turn; strategies for parents of the gifted and talented. New York: Teachers College Pr.

Hamiyeh, R. (2012). Lebanon launcher, the national plan to integrate children with special needs in to the educational system in public schools. Arabian Business, Retrieved on November 15th, 2015 from: http://arabic.arabianbusiness.com/business/education/2012/feb/21/69/15

Johnson, B. (2011). How to support gifted students in your classroom. Retrieved on November 15th, 2015 from: http://www.edutopia.org

Mayor, F. (1994). The Salamanca statement and framework for action. Retrieved from: http://www.unesco.org/education/pdf/SALAMA_E.PDF

Renzulli, J.S. (1998). The three-ring conception of giftedness. Retrieved from: http://gifted.uconn.edu/wp-content/uploads/sites/961/2015/01/The_ThreeRing_Conception_of_Giftedness.pdf

Sarouphim, K. (2010). A model for the education of gifted learners in Lebanon. International Journal of Special Education, 25, 71 - 79.

Siegle, D. \& McCoach, D.B. (2005). Motivating gifted students. Waco, Texas: Pruf Rock Press.

The Daily Star. (2012). More special needs students to attend school, says minister. Retrieved on November 15th, 2015 from: http://www.dailystar.com.lb/News/LocalNews/2012/Feb-21/164047-more-special-needs-students-to-attend-school-says$\underline{\text { minister.ashx }}$

Wehbi, S. (2006). The challenges of inclusive education in Lebanon. Disability and Society, 21, 331-343.

Winebrenner, S. (2001). Teaching gifted kids in the regular classrooms. Minneapolis: Free Spirit Publishing. 


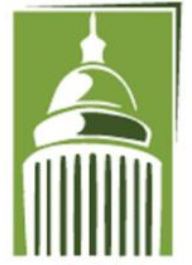

\section{Global Proceedings Repository \\ American Research Foundation}

ISSN 2476-017X

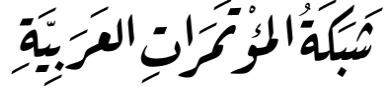

http://arab.kmshare.net/

AR F

Available online at http://proceedings.sriweb.org

Witty, P.A. (1980). Reading for the gifted and creative student. Newark, DE:

International Reading Association. 